\title{
ANALISIS PERBANDINGAN FUZZY TSUKAMOTO DAN SUGENO DALAM MENENTUKAN JUMLAH PRODUKSI KAIN TENUN MENGGUNAKAN BASE RULE DECISION TREE
}

\author{
Tundo*1, Riolandi Akbar $^{2}$, Enny Itje Sela ${ }^{3}$ \\ 1,2 Magister Informatika UIN Sunan Kalijaga Yogyakarta, ${ }^{3}$ Informatika Universitas Teknologi Yogyakarta \\ Email: 1amrimujahit@yahoo.co.id, ${ }^{2}$ riolandiakbar@gmail.com, ${ }^{3}$ ennysela@uty.ac.id \\ *Penulis Korespondensi
}

(Naskah masuk: 04 Februari 2019, diterima untuk diterbitkan: 14 Januari 2020)

\begin{abstract}
Abstrak
Penelitian ini menerangkan tentang analisis perbandingan fuzzy Tsukamoto dan Sugeno dalam menentukan jumlah produksi kain tenun dengan menggunakan base rule decision tree. Dari hasil analisis penelitian ini, maka ditemukan beberapa perbedaan yang sangat signifikan: (1) Metode fuzzy Tsukamoto dari hasil yang diperoleh lebih mendekati dari data sesungguhnya, dibandingkan dengan fuzzy Sugeno, (2) Selisih yang diperoleh dengan menggunakan fuzzy Tsukamoto dengan data produksi sesungguhnya selalu konsisten yaitu hasil fuzzy Tsukamoto selalu lebih besar, sedangkan untuk fuzzy Sugeno tidak konsisten, (3) Hasil selisih untuk fuzzy Tsukamoto relatif mendekati dari data produksi sesungguhnya, sedangkan untuk fuzzy Sugeno relatif jauh selisih yang dihasilkan. Sehingga dapat disimpulkan bahwa metode yang paling mendekati nilai kebenaran adalah produksi yang mengunakan metode Tsukamoto dengan keakuratan yang diperoleh menggunakan base rule decision tree sebesar $83.3333 \%$.
\end{abstract}

Kata kunci: Logika fuzzy, Metode Tsukamoto, Metode Sugeno, Rule decision tree.

\section{COMPARATIVE ANALYSIS OF FUZZY TSUKAMOTO AND SUGENO IN DETERMINING THE AMOUNT OF WEAVING FABRIC PRODUCTION USING THE DECISION TREE BASE RULE}

\begin{abstract}
This study describes the comparative analysis of fuzzy Tsukamoto and Sugeno determining the amount of woven fabric production using a decision tree base rule. From the results the analysis of this study, we found several very significant differences: (1) The fuzzy Tsukamoto method of the results obtained is closer to the actual, compared to fuzzy Sugeno, (2) The difference obtained by using fuzzy Tsukamoto with actual production data is always consistent is that Tsukamoto fuzzy results are always greater, while for Sugeno's fuzzy inconsistency, (3) The difference results for fuzzy Tsukamoto are relatively close to the actual production data, whereas Sugeno fuzzy is relatively far from the difference produced. So it can be concluded that the method closest to the truth value is production using the Tsukamoto method with the accuracy obtained using the base rule decision tree of $83.3333 \%$.
\end{abstract}

Keywords: Fuzzy Logic, Tsukamoto Method, Sugeno Method, Decision tree rule.

\section{PENDAHULUAN}

Era persaingan semakin berkembang pada saat ini telah menyebabkan perusahaan yang bergerak dibidang industri harus semakin memperhatikan dalam menentukan kelangsungan hidup perusahaan agar dapat bertahan terutama dalam menentukan jumlah produksi (Solikin, 2013). Seperti yang terjadi pada perusahaan kain tenun Mlaki Wanarejan Utara Pemalang, dimana permasalahan berupa penentuan produksi kain tenun tidak memiliki prediksi sekiranya berapa kain tenun yang akan terbentuk jika dipengaruhi oleh permintaan, stok, dan biaya produksi. Penentuan prediksi merupakan hal yang penting dalam jalannya suatu perusahaan. Apabila dalam suatu perusahaan tidak memiliki perkiraan jumlah produksi maka proses menjadi tidak terkendali maka menyebabkan permasalahan pada keuangan perusahaan. Oleh karena itu, penentuan jumlah produksi sangat diperlukan untuk menjaga kestabilan jumlah stok kain tenun. 
Dalam menyelesaikan masalah itu, pihak perusahaan hendaknya dapat membuat suatu keputusan yang tepat untuk menentukan berapa banyak jumlah produksi kain tenun yang akan diproduksi (Tundo and Sela, 2018).

Maka, dibutuhkan suatu sistem yang dapat menangani masalah itu. Dalam hal ini peneliti menggunakan penerapan logika fuzzy Tsukamoto dan Sugeno dengan menggunakan base rule decision tree. Alasan digunakannya base rule decision tree dalam penelitian ini yaitu, karena konsep decision tree memangkas seleksi variable input yang sekiranya tidak diperlukan, dengan hasil yang dapat dipertanggungjawabkan karena adanya akurasi kebenarannya (Sela et al., 2015).

Berikut beberapa penelitian yang serupa yang peneliti ambil sebagai bahan dalam pembuatan penelitian ini. Pertama menurut (Selywita and Hamdani, 2013) melakukan penelitian mengenai supplier obat dengan menggunakan metode fuzzy Tsukamoto dengan rule yang digunakan adalah rule monoton, dengan kriteria yang ada yaitu, harga, pengalaman, dan waktu. Menurut (Hidayati et al., 2013) melakukan penelitian mengenai optimalisasi mitra bisnis kelayakan untuk revitalisasi kelapa sawit dengan menggunakan fuzzy Analytic Hierarchy Process (AHP) dengan akurasi sebesar 55\%. Kedua menurut (Tseng, Konada and Kwon, 2016) melakukan penelitian memprediksi kekasaran permukaan dalam operasi pemesinan menggunakan teori himpunan fuzzy Tsukamoto dengan akurasi yang dihasilkan sebesar 95\%. Ketiga menurut (Juliansyah, 2015) melakukan penelitian berkaitan tentang penerapan metode fuzzy Tsukamoto dalam memprediksi minyak kelapa sawit dengan menggunakan kriteria permintaan dan persediaan dengan akurasi sebesar 82\%. Keempat menurut (Sigit, 2015) mekakukan penelitian mengenai implementasi klasikfikasi fuzzy-C4.5 sebagai pendukung dalam pemilihan spesialisasi siswa dengan akurasi yang didapat sebesar $86.51 \%$, dan yang terakhir menurut (Sukandy, Basuki and Puspasari, 2014) melakukan penelitian tentang prediksi produksi minyak kelapa sawit dengan kriteria persediaan dan jumlah permintaan diperoleh akurasi sebesar $86.67 \%$

Berdasarkan dari penelitian sebelumnya, maka disini peneliti menggunakan base rule decision tree dengan metode logika fuzzy Tsukamoto dan Sugeno, dengan tujuan untuk mengetahui bahwa rule dalam fuzzy inference system dapat pula dibentuk dengan menggunakan decision tree.

\section{METODOLOGI PENELITIAN}

Metode penelitian yang digunakan dalam penelitian ini adalah sebagai berikut:

a. Pembuatan rule decision tree

Pembuatan rule decision tree yakni, menggunakan tools weka dengan menggunakan data kain batik Mlaki Wanarejan Utara Pemalang dari bulan September 2014 sampai dengan bulan Februari 2017. Dalam pembuatan rule decision tree data yang digunakan hanya biaya produksi, permintaan, stok, dan jumlah produksi untuk data bulan dan tahun tidak diikutsertakan. Langkah berikutnya membuat nilai jumlah produksi menjai nilai linguistik yang terdiri dari Banyak dan Sedikit, setelah itu, implementasikan menggunakan tools weka maka akan terbentuk pohon keputusan yang akan digunakan sebagai rule untuk digunakan dalam menentukan prediksi jumlah produksi kain batik menggunakan metode fuzzy Tsukamoto dan Sugeno.

b. Implementasi Fuzzy Tsukamoto dan Sugeno Setelah rule decision tree terbentuk, maka langkah selanjutnya yaitu, mengimplementasikan rule tersebut ke dalam metode fuzzy Tsukamoto dan Sugeno, yang menjadi pembeda antara kedua metode tersebut adalah terletak pada aturannya, dimana untuk fuzzy Sugeno mengkombinasikan nilai konstanta pada setiap aturan (Kusumadewi, 2013).

c. Hasil perbandingan

Hasil perbandingan berarti membandingkan antara kedua metode fuzzy tersebut dengan menggunakan aturan decision tree dengan data sesungguhnya di perusahaan kain tenun mana metode yang nilainya mendekati dengan data sesungguhnya.

\section{PENGEMBANGAN SISTEM}

Pengembangan sistem yang akan dibuat dalam sistem penerapan metode fuzzy Tsukamoto dan Sugeno untuk memprediksi jumlah produksi kain tenun dapat dilihat pada Gambar 1.

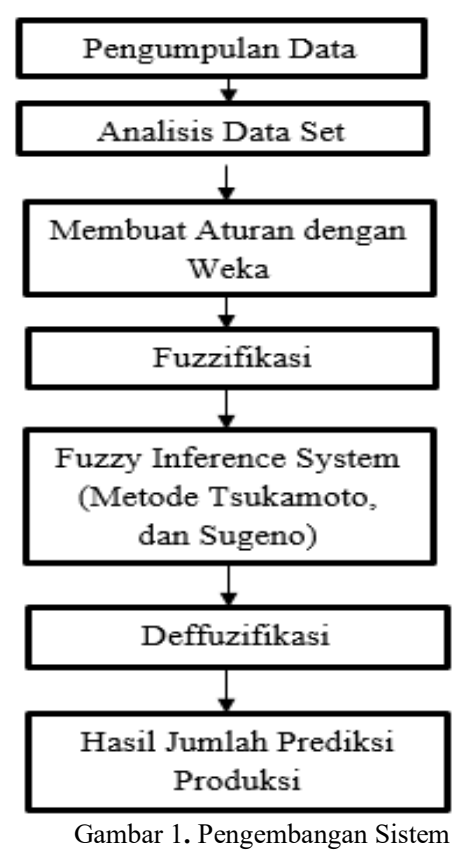


Dari Gambar 1. bahwa pengembangan sistem yang dikembangkan adalah sebanyak 6 tahapan, penjelasannya sebagai berikut :

a. Pengumpulan Data

Pengumpulan data dilakukan di Mlaki Wanarejan Utara Pemalang, tepatnya di Pondok Pesantren An-nur Pemalang. Kegiatan pengumpulan data dimulai dari bulan September 2014 sampai dengan bulan Februari 2017. Pengumpulan data dilakukan dengan cara wawancara secara langsung kepada pihak kain tenun yaitu kepada Bu Nyai Diana selaku pemilik pengusaha kain tenun. Data yang diperoleh adalah data stok, permintaan, biaya produksi, serta jumlah produksi. Adapun data stok, permintaan, biaya produksi, serta jumlah produksi periode perbulan dapat dilihat di Tabel 1.

\begin{tabular}{|c|c|c|c|c|c|}
\hline Bln & Thn & $\begin{array}{l}\text { Biaya } \\
\text { produksi }\end{array}$ & $\begin{array}{l}\text { Permi } \\
\text { ntaan }\end{array}$ & Stok & $\begin{array}{l}\text { Jmlh } \\
\text { Produk } \\
\text { si }\end{array}$ \\
\hline 09 & 2014 & Rp 1.500 .000 & 100 & 15 & 120 \\
\hline 10 & 2014 & Rp 1.200 .000 & 110 & 12 & 128 \\
\hline 11 & 2014 & Rp 1.000 .000 & 200 & 50 & 205 \\
\hline 12 & 2014 & Rp 1.100 .000 & 300 & 75 & 305 \\
\hline 01 & 2015 & Rp 1.600 .000 & 400 & 10 & 410 \\
\hline 02 & 2015 & Rp 1.000 .000 & 50 & 5 & 106 \\
\hline 03 & 2015 & Rp 900.000 & 230 & 12 & 280 \\
\hline 04 & 2015 & Rp 1.400 .000 & 124 & 100 & 180 \\
\hline 05 & 2015 & $\mathrm{Rp} 900.000$ & 450 & 100 & 465 \\
\hline 06 & 2015 & Rp 1.100 .000 & 105 & 98 & 250 \\
\hline 07 & 2015 & Rp 1.600 .000 & 290 & 230 & 100 \\
\hline 08 & 2015 & Rp 1.000 .000 & 50 & 10 & 100 \\
\hline 09 & 2015 & Rp 900.000 & 50 & 15 & 80 \\
\hline 10 & 2015 & Rp 1.400 .000 & 75 & 34 & 116 \\
\hline 11 & 2015 & Rp 900.000 & 120 & 100 & 122 \\
\hline 12 & 2015 & Rp 1.200 .000 & 126 & 59 & 160 \\
\hline 01 & 2016 & Rp 7.890 .400 & 220 & 33 & 224 \\
\hline 02 & 2016 & $\operatorname{Rp} 8.806 .250$ & 245 & 24 & 250 \\
\hline 03 & 2016 & Rp 14.547.925 & 409 & 65 & 413 \\
\hline 04 & 2016 & Rp 10.497 .050 & 292 & 22 & 298 \\
\hline 05 & 2016 & Rp 7.608.600 & 211 & 32 & 216 \\
\hline 06 & 2016 & Rp 12.082.175 & 340 & 58 & 343 \\
\hline 07 & 2016 & $\mathrm{Rp} 7.925 .625$ & 215 & 27 & 225 \\
\hline 08 & 2016 & Rp 16.344 .400 & 485 & 64 & 464 \\
\hline 09 & 2016 & Rp 16.600 .000 & 450 & 40 & 472 \\
\hline 10 & 2016 & Rp 8.806.250 & 245 & 38 & 250 \\
\hline 11 & 2016 & $\operatorname{Rp} 8.665 .350$ & 243 & 26 & 246 \\
\hline 12 & 2016 & $\operatorname{Rp} 8.348 .325$ & 300 & 30 & 237 \\
\hline 01 & 2017 & Rp 10.664.000 & 242 & 37 & 248 \\
\hline 02 & 2017 & Rp 12.900 .000 & 276 & 44 & 300 \\
\hline 03 & 2007 & $\operatorname{Rp} 6.000 .000$ & 320 & 60 & $?$ \\
\hline
\end{tabular}

Dapat dilihat pada Tabel 1 dari bulan September 2014 sampai dengan bulan Februari 2017, dapat disimpulkan bahwa Stok kain tenun terbanyak sampai 230 biji perbulan, dan terkecil mencapai 5 biji perbulan. Permintaan kain tenun terbesar mencapai 485 biji perbulan, dan permintaan terkecil mencapai 50 biji perbulan. Biaya produksi yang harus dikeluarkan perbulan terbesar mencapai Rp 16.600.000, dan biaya produksi terkecil mencapai Rp 900.000 . Jumlah produksi kain tenun terbanyak sebesar 472 biji perbulan, dan terkecil sebesar 80 biji perbulan. Diketahui bahwa stok dibulan maret sebanyak 60, permintaan sebanyak 320 dan biaya produksi hanya ada $\mathrm{Rp} 6.000 .000$, ditanyakan berapa produksi yang harus diproduksi dengan metode Fuzzy Inference System dengan menggunakan metode Tsukamoto dan Sugeno.

b. Analisis Data Set

Analisis data set berdasarkan data di Pondok Pesantren An-nur Pemalang yang akan digunakan untuk proses Fuzzy Inference System Tsukamoto dan Sugeno adalah menggunakan data stok, permintaan, biaya produksi, serta jumlah produksi sebagai data latih sebelum diproses dengan data uji yang akan diprediksi.

c. Membuat Aturan dengan Weka

Membuat rule dengan decision tree dengan menggunakan tools weka, dengan cara menggenerate semua data stok, permintaan, biaya produksi, dan jumlah produksi kemudian diproses dengan menggunakan Algoritma C4.5 untuk mengkontruksi pohon keputusan dari data pelatihan tersebut. Algoritma untuk membangun pohon keputusan adalah C4.5 dalam Weka dikenal dengan nama J48 sehingga akan terbentuknya klasifikasi aturan, selanjutnya hasil klasifikasi digambarkan dalam bentuk pohon keputusan (decision tree) yang akan ditunjukan diperhitungan dan implementasi. Aturan yang terbentuk dari Weka adalah If.... And..... Then....

d. Fuzzifikasi

Fuzzisifikasi adalah langkah-langkah untuk membuat fungsi keanggotaan berdasarkan variabel-variabel yang sudah ditentukan beserta semesta pembicaraan, variabel itu adalah stok, permintaan, biaya produksi, serta jumlah produksi, setelah itu mencari derajat keanggotaan suatu himpunan fuzzy, berdasarkan nilai linguistik yang telah ditentukan yaitu sedikit dan banyak.

\section{e. Fuzzy Inference System}

Pada tahap Fuzzy Inference System menggunakan metode Tsukamoto dan Sugeno untuk melakukan proses perhitungan sampai dengan diperoleh hasil prediksi jumlah produksi kain tenun. Adapun langkah-langkah Fuzzy Inference System menentukan himpunan fuzzy dengan mencari nilai keanggotaan dengan menggunakan kurva linier naik dan turun seperti persamaan berikut:

$$
\begin{aligned}
& \boldsymbol{\mu}_{[x]}\left\{\begin{array}{lr}
0 & x \leq j \\
\frac{x-j}{k-j}, & j \leq x \leq k \\
1 & x \geq k
\end{array}\right. \\
& \boldsymbol{\mu}_{[x]}\left\{\begin{array}{lr}
1 & x \leq j \\
\frac{k-x}{k-j}, & j \leq x \leq k \\
0 & x \geq k
\end{array}\right.
\end{aligned}
$$


Kemudian menentukan himpunan operasi AND yang berbentuk if.. then...

$$
\mu \mathrm{A} \cap \mathrm{B}=\min (\mu \mathrm{A}[\mathrm{x}], \mu \mathrm{B}[\mathrm{y}])
$$

f. Deffuzifikasi

Deffuzifikasi adalah cara yang terakhir untuk memperoleh hasil prediksi kain tenun dimana dengan menggunakan persamaan:

$$
Z=\frac{\Sigma(\alpha * z)}{\Sigma \alpha}
$$

g. Hasil jumlah Prediksi

Pada tahap ini adalah tahap terakhir yaitu diperolehnya hasil prediksi jumlah produksi kain tenun dari Fuzzy Inference System menggunakan metode Tsukamoto dan Sugeno.

\section{PERHITUNGAN DAN IMPLEMENTASI}

\subsection{Perhitungan Fuzzy Inference System}

Berikut contoh perhitungan manual fuzzy Tsukamoto dan fuzzy Sugeno berdasarkan data stok, permintaan, serta biaya produksi yang nampak pada Tabel 1.

\section{a. Metode Fuzzy Tsukamoto}

\section{Contoh kasus:}

Perusahaan kain tenun Mlaki wanarejan utara Pemalang, adalah suatu perusahaan pembuat kain tenun, dari sampel data produksi dari bulan September tahun 2014 sampai bulan February tahun 2017 yang diketahui perbulannya, biaya produksi maksimum $\mathrm{Rp} 16.600 .000$, biaya produksi minimum $\mathrm{Rp} 900.000$, permintaan maksimum 485 perbiji, permintaan minimum 50 perbiji, stok maksimum 230 perbiji dan stok minimum 5 perbiji, serta Jumlah produksi minimum 80 perbiji, jumlah produksi maksimum 472 perbiji. Diketahui biaya produksi saat ini pada bulan Maret 2017 yaitu: Rp 6.000.000 dan permintaan saat ini yaitu: 320 perbiji, stok saat ini yaitu 60 perbiji. Berapa jumlah kain tenun yang harus diproduksi Perusahaan kain tenun Mlaki wanarejan utara Pemalang pada bulan Maret $2017 ?$

\section{Penyelesaian:}

Dalam permasalahan ini terdapat empat variabel, yaitu: tiga variabel input, yaitu: stok, permintaan, dan biaya produksi sedangkan untuk output terdapat satu variabel, yaitu: jumlah produksi kain tenun. Variabel stok, permintaan, biaya produksi, dan jumlah produksi kain tenun memiliki dua nilai linguistik, yaitu banyak dan sedikit. Berdasarkan rule yang menggunakan tools weka 3.6 yang diperoleh dari Tabel 2.1 sehingga menghasilkan

\begin{tabular}{|c|c|}
\hline Rule & Kondisi \\
\hline R1 & 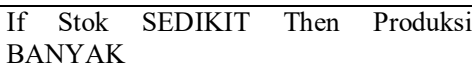 \\
\hline $\mathrm{R} 2$ & $\begin{array}{l}\text { If Stok BANYAK And Biaya produksi } \\
\text { SEDIKIT And Permintaan SEDIKIT } \\
\text { Then Produksi SEDIKIT }\end{array}$ \\
\hline R3 & $\begin{array}{l}\text { If Stok BANYAK And Biaya produksi } \\
\text { SEDIKIT And Permintaan BANYAK } \\
\text { Them Produksi BANYAK }\end{array}$ \\
\hline R4 & $\begin{array}{l}\text { If Stok BANYAK And Biaya produksi } \\
\text { BANYAK Then Produksi SEDIKIT }\end{array}$ \\
\hline
\end{tabular}
rule berikut:

\section{Langkah 1:}

Menentukan kriteria variabel yang terkait untuk pembuatan bentuk kurva untuk proses fuzzifikasi. Pada kasus ini, ada 4 variabel yang akan dimodelkan, yaitu:

a. Stok (x), terdiri atas 2 himpunan fuzzy, yaitu SEDIKIT dan BANYAK .Berdasarkan dari data stok maksimal dan minimal dari Tabel 2.1 data sampel, maka fungsi keanggotaan dirumuskan sebagai berikut:

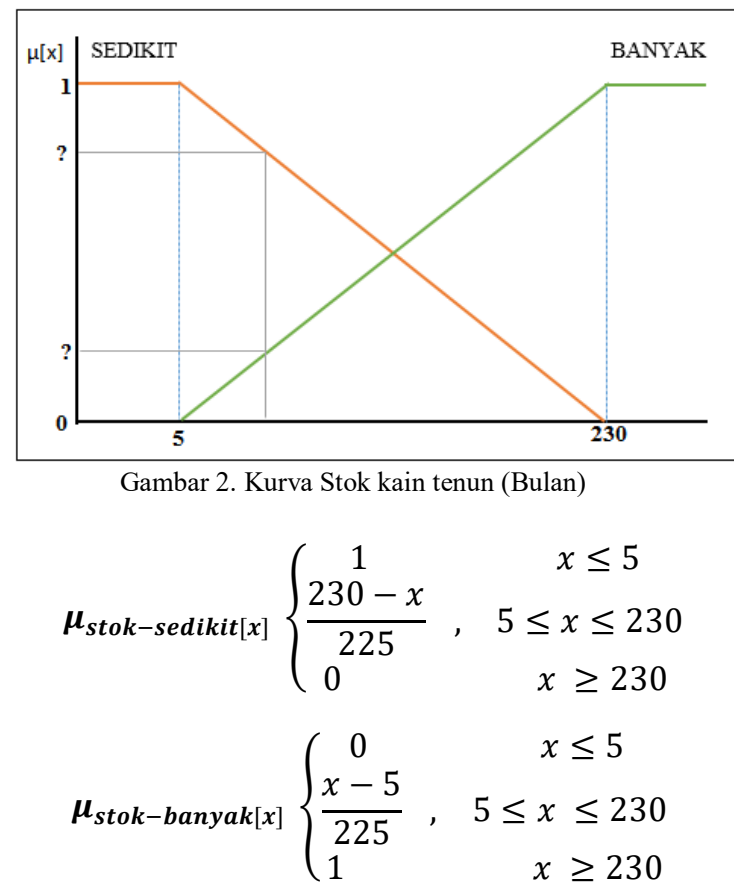

Jika diketahui stok sebanyak 60 biji, maka:

$$
\begin{aligned}
& \mu_{\text {stok-sedikit }[60]}=\frac{230-60}{225}=0.755 \\
& \mu_{\text {stok-banyak }[60]}=\frac{60-5}{225}=0.244
\end{aligned}
$$

b. Permintaan (y), terdiri atas dua himpunan fuzzy, yakni SEDIKIT dan BANYAK .Berdasarkan dari data permintaan maksimal dan minimal dari Tabel 2.1 data sampel, maka fungsi keanggotaan dirumuskan sebagai berikut : 


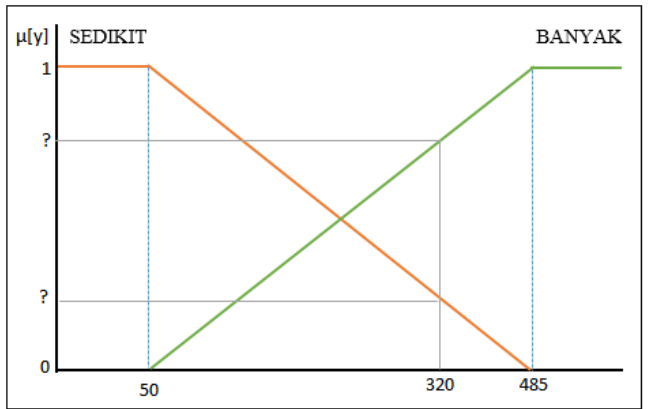

Gambar 3. Kurva Permintaan kain tenun (Bulan)

$$
\begin{gathered}
\boldsymbol{\mu}_{\text {permintaan-sedikit }[y]}\left\{\begin{array}{cc}
1 & y \leq 50 \\
\frac{485-y}{435}, & 50 \leq y \leq 485 \\
0 & y \geq 485
\end{array}\right. \\
\boldsymbol{\mu}_{\text {permintaan-banyak }[y]}\left\{\begin{array}{cc}
0 & y \leq 50 \\
\frac{y-50}{435}, & 50 \leq y \leq 485 \\
1 & y \geq 485
\end{array}\right.
\end{gathered}
$$

Jika diketahui stok sebanyak 320 biji, maka:

$$
\begin{gathered}
\mu_{\text {permintaan-sedikit }[320]}=\frac{485-320}{435}=0.379 \\
\mu_{\text {permintaan-banyak }[320]}=\frac{320-50}{435}=0.621
\end{gathered}
$$

c. Biaya produksi (w), terdiri atas dua himpunan fuzzy, yaitu SEDIKIT dan BANYAK .Berdasarkan dari data biaya produksi maksimal dan minimal dari Tabel 2.1 data sampel, maka fungsi keanggotaan dirumuskan sebagai berikut :

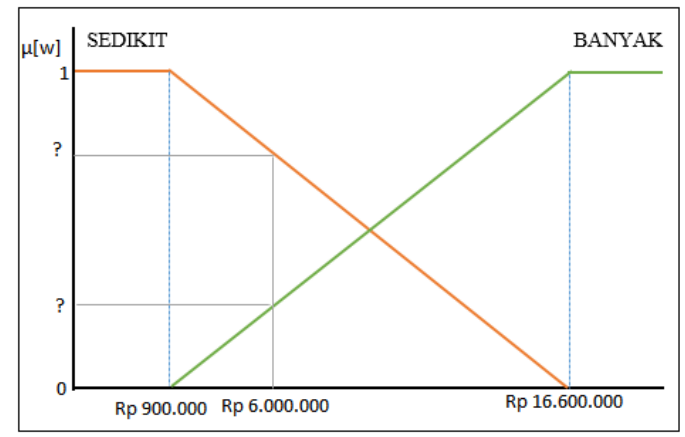

Gambar 4. Kurva Biaya produksi kain tenun (Bulan)

$$
\begin{gathered}
\boldsymbol{\mu}_{\text {biaya-sedikit }[\boldsymbol{w}]}\left\{\begin{array}{cc}
1 & w \leq 900000 \\
\frac{16600000-w}{15700000}, & 900000 \leq w \leq 16600000 \\
0 & w \geq 16600000
\end{array}\right. \\
\boldsymbol{\mu}_{\text {biaya-banyak }[\boldsymbol{w}]}\left\{\begin{array}{cc}
0 & w \leq 900000 \\
\frac{w-900000}{15700000}, & 900000 \leq w \leq 16600000 \\
1 & w \geq 16600000
\end{array}\right.
\end{gathered}
$$

Jika diketahui biaya produksi sebanyak 6000000 rupiah, maka:

$$
\begin{aligned}
\mu_{\text {biaya-sedikit }[6000000]} & =\frac{16600000-6000000}{15700000} \\
& =0.675 \\
\mu_{\text {biaya-banyak }[6000000]} & =\frac{6000000-900000}{15700000} \\
& =0.325
\end{aligned}
$$

d. Jumlah produksi (z), terdiri atas dua himpunan fuzzy, yakni SEDIKIT dan BANYAK. Berdasarkan dari data produksi maksimal dan minimal dari Tabel 2.1 data sampel, maka fungsi keanggotaan dirumuskan sebagai berikut :

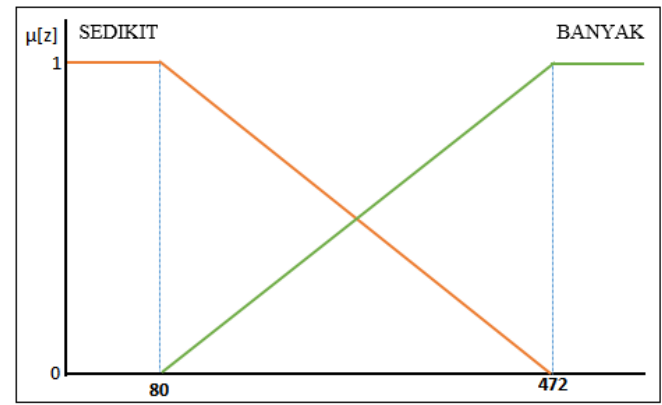

Gambar 5. Kurva Produksi kain tenun (Bulan)

$$
\begin{gathered}
\boldsymbol{\mu}_{\text {produksi-sedikit }[z]}\left\{\begin{array}{cc}
1 & z \leq 80 \\
\frac{472-z}{392}, & 80 \leq z \leq 472 \\
0 & z \geq 472
\end{array}\right. \\
\boldsymbol{\mu}_{\text {produksi-banyak }[\mathrm{z}]}\left\{\begin{array}{cc}
0 & z \leq 80 \\
\frac{z-80}{392}, & 80 \leq z \leq 472 \\
1 & z \geq 472
\end{array}\right.
\end{gathered}
$$

\section{Langkah 2:}

Aplikasi fungsi implikasi menggunakan fungsi MIN, dapat mencari nilai z pada setiap aturannya:

R1: If Stok SEDIKIT Then Jumlah produksi BANYAK

$$
\begin{aligned}
\alpha_{- \text {predikat } 1} & =\mu_{\text {stok-sedikit }} \\
& =\left(\mu_{\text {Stok-sedikit }}[60]\right) \\
=0.756 &
\end{aligned}
$$

$$
\begin{gathered}
\boldsymbol{\mu}_{\text {Produksi-banyak }[z]}\left\{\begin{array}{cc}
0 & z \leq 80 \\
\frac{z-80}{392}, & 80 \leq z \leq 472 \\
1 & Z \geq 472
\end{array}\right. \\
\frac{Z 1-80}{392}=0.756 \\
Z_{1}=376.178
\end{gathered}
$$

R2: If Stok BANYAK And Biaya produksi SEDIKIT And Permintaan SEDIKIT Then Jumlah produksi SEDIKIT 


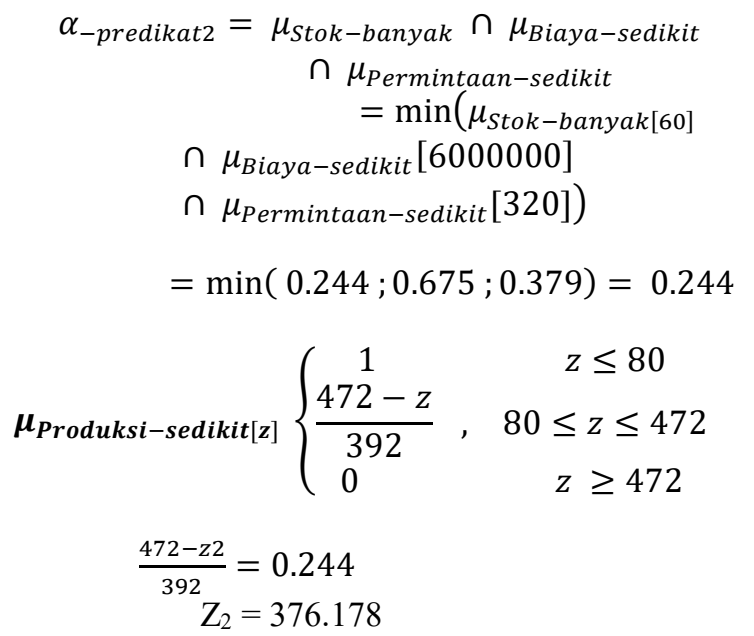

R3: If Stok BANYAK And Biaya produksi SEDIKIT And Permintaan BANYAK Then Jumlah produksi BANYAK

$$
\begin{gathered}
\alpha_{\text {-predikat } 3}=\mu_{\text {Stok-banyak }} \cap \mu_{\text {Biaya-sedikit }} \\
\cap \mu_{\text {Permintaan-banyak }} \\
=\min \left(\mu_{\text {Stok-banyak }[60]}\right. \\
\cap \mu_{\text {Biaya-sedikit }}[6000000] \\
\left.\cap \mu_{\text {Permintaan-banyak }}[320]\right) \\
=\min (0.244 ; 0.675 ; 0.621) \\
=0.244
\end{gathered}
$$

$\boldsymbol{\mu}_{\text {Produksi-banyak }[z]}\left\{\begin{array}{cc}0 & z \leq 80 \\ \frac{z-80}{392}, & 80 \leq z \leq 472 \\ 1 & z \geq 472\end{array}\right.$

$$
\begin{gathered}
\frac{z 3-80}{392}=0.244 \\
Z_{3}=175.822
\end{gathered}
$$

R4: If Stok BANYAK And Biaya produksi BANYAK Then Jumlah Produksi SEDIKIT

$$
\begin{aligned}
& \quad \alpha-\text { predikat } 4 \\
& =\mu_{\text {Stok-banyak }} \\
& \cap \mu_{\text {Biaya-Banyak }} \\
& =\min \left(\mu_{\text {Stok-banyak }[60]}\right. \\
& \left.\cap \mu_{\text {Biaya-Banyak }}[6000000]\right) \\
& =\min (0.244444444 ; 0.32484076
\end{aligned}
$$$$
=0.244
$$

$$
\begin{gathered}
\boldsymbol{\mu}_{\text {Produksi-sedikit }[z]}\left\{\begin{array}{cc}
1 & z \leq 80 \\
\frac{472-z}{392}, & 80 \leq z \leq 472 \\
0 & z \geq 472
\end{array}\right. \\
\frac{472-z 4}{392}=0.244 \\
\mathrm{Z}_{4}=376.178
\end{gathered}
$$

\section{Langkah 3:}

Hasil atau output diperoleh dengan menggunakan rata-rata terbobot yaitu:

$$
\begin{aligned}
z & =\frac{\alpha_{- \text {predikat } 1} * z 1+\alpha_{\text {-predikat } 2} * z 2+\alpha_{- \text {predikat } 3} * z 3+\alpha_{\text {-predikat } 4} * z 4}{\alpha_{\text {predikat } 1}+\alpha_{\text {-predikat } 2}+\alpha_{\text {-predikat } 3}+\alpha_{\text {-predikat } 4}} \\
= & \frac{0.756 * 376.178+0.244 * 376.178+0.244 * 175.822+0.244 * 376.178}{0.756+0.244+0.244+0.244} \\
z & =\frac{511.111}{1.489} \\
& =343.284 \approx 343
\end{aligned}
$$

Jadi jumlah produksi kain tenun yang harus diproduksi oleh perusahaan kain tenun mlaki wanarejan utara pemalang adalah sebanyak 343 perbiji.

b. Metode Fuzzy Sugeno

\section{Langkah 1:}

Sama seperti langkah diatas, maka disini peneliti langsung menuju ke aturan atau rule yang dikombinasikan dengan menggunakan orde 0 dan orde 1 dimana hasil yang dikeluarkan berupa konstanta. Seperti berikut:

Tabel 3. Rule decision tree yang dikombinasikan

\begin{tabular}{ll}
\hline Rule & Kondisi \\
\hline R1 & If Stok SEDIKIT Then Produksi = Permintaan \\
R2 & $\begin{array}{l}\text { If Stok BANYAK And Biaya produksi SEDIKIT } \\
\text { And Permintaan SEDIKIT Thren Produksi = } \\
\text { (Permintaan - Stok) + 150 }\end{array}$ \\
R3 & $\begin{array}{l}\text { If Stok BANYAK And Biaya produksi SEDIKIT } \\
\text { And Permintaan BANYAK Then Produksi =1.25* }\end{array}$ \\
R4 Permintaan - Stok \\
If Stok BANYAK And Biaya produksi BANYAK \\
Then Produksi = Permintaan+200
\end{tabular}

Langkah 2:

Aplikasi fungsi implikasi dengan menggunakan kombinasi orde 0 dan orde 1 seperti berikut:

R1: If Stok SEDIKIT Thren Jumlah produksi = Permintaan

$$
\begin{aligned}
\alpha_{- \text {predikat } 1} & =\mu_{\text {stok-sedikit }} \\
& =\left(\mu_{\text {Stok-sedikit }}[60]\right) \\
=0.756 &
\end{aligned}
$$

Sehingga didapatkan nilai $Z_{1}=$ Permintaan

$$
=320
$$

R2: If Stok BANYAK And Biaya produksi SEDIKIT And Permintaan SEDIKIT Thren Jumlah produksi $=($ Permintaan - Stok $)+150$

$$
\begin{aligned}
& \alpha \text {-predikat } 2 \\
& =\mu_{\text {Stok-banyak }} \cap \mu_{\text {Biaya-sedikit }} \\
& \cap \mu_{\text {Permintaan-banyak }} \\
& =\min \left(\mu_{\text {Stok-banyak }}[60]\right. \\
& \cap \mu_{\text {Biaya-sedikit }}[6000000] \\
& \left.\cap \mu_{\text {Permintaan-sedikit }}[320]\right)
\end{aligned}
$$




$$
=\min (0.244 ; 0.675 ; 0.379
$$$$
=0.244
$$

Sehingga didapatkan nilai $Z_{2}$ :

$=($ Permintaan - Stok $)+150$

$=(320-60)+150$

$=410$

R3: If Stok BANYAK And Biaya produksi SEDIKIT And Permintaan BANYAK Thren Jumlah produksi $=1.25^{*}$ Permintaan - Stok

$$
\begin{gathered}
\alpha_{\text {-predikat } 3}=\mu_{\text {Stok-banyak }} \\
\cap \mu_{\text {Biaya-sedikit }} \\
\cap \mu_{\text {Permintaan-banyak }} \\
=\min \left(\mu_{\text {Stok-banyak }}[60]\right. \\
\cap \mu_{\text {Biaya-sedikit }}[600000] \\
\left.\cap \mu_{\text {Permintaan-banyak }}[320]\right) \\
=\min (0.244 ; 0.675 ; 0.621) \\
=0.244
\end{gathered}
$$

Sehingga didapatkan nilai $Z_{3}$ :

$$
\begin{aligned}
& =1.25 * \text { Permintaan - Stok } \\
& =1.25 * 320-60 \\
& =340
\end{aligned}
$$

R4: If Stok BANYAK And Biaya produksi BANYAK Thren Jumlah Produksi = Permintaan +200

$$
\begin{aligned}
& \alpha_{\text {-predikat } 4}=\mu_{\text {Stok-banyak }} \\
& \cap \mu_{\text {Biaya-Banyak }} \\
& =\min \left(\mu_{\text {Stok-banyak }}[60]\right. \\
& \left.\cap \mu_{\text {Biaya-Banyak }}[6000000]\right) \\
& =\min (0.244 ; 0.325) \\
& =0.244
\end{aligned}
$$

Sehingga didapatkan nilai $Z_{4}$ :

$$
\begin{aligned}
& =\text { Permintaan }+200 \\
& =320+200 \\
& =520
\end{aligned}
$$

\section{Langkah 3:}

Hasil akhir atau output diperoleh dengan menggunakan rata-rata terbobot yaitu:

$$
\begin{aligned}
& z=\frac{\alpha_{- \text {predikat } 1} * z 1+\alpha_{- \text {predikat } 2} * z 2+\alpha_{- \text {predikat } 3} * z 3+\alpha_{- \text {predikat } 4} * z 4}{\alpha_{- \text {predikat } 1}+\alpha_{\text {-predikat } 2}+\alpha_{- \text {predikat } 3}+\alpha_{- \text {predikat } 4}} \\
& z=\frac{0.756 * 320+0.244 * 410+0.244 * 340+0.244 * 520}{0.756+0.244+0.244+0.244} \\
& z=\frac{552.222}{1.489} \\
& =370.896 \approx 371
\end{aligned}
$$

Jadi jumlah produksi kain tenun yang harus diproduksi oleh perusahaan kain tenun mlaki wanarejan utara pemalang sebanyak 371 perbiji.

\subsection{Implementasi Weka untuk Membuat Rule decision tree}

Langkah awal untuk membuat aturan atau rule pada weka yaitu, mengisikan semua data yang terkait pada microsoft excel seperti data stok, permintaan, biaya produksi, serta jumlah produksi, kemudian simpan data tersebut dengan format (*.csv), selanjutnya panggil data tersebut ke weka. Setelah itu, pilih menu classify, pada test options pilih use training set, pada tombol choose pilih file trees, kemudian pilih J48, setelah itu klik tombol start, maka akan muncul tampilan klasifikasi seperti pada Gambar 6 berikut :

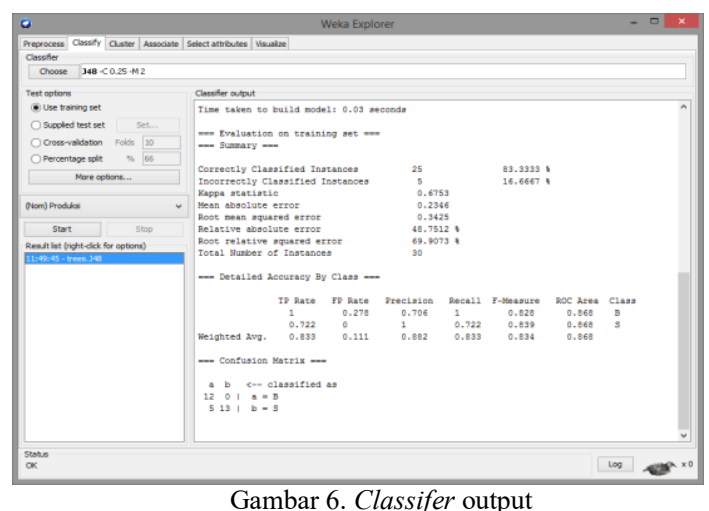

Dari Gambar 6 dapat diketahui bahwa data yang dimasukan sebanyak 30 yang benar dalam klasifikasi sebanyak 25 dan klasifikasi yang salah sebanyak 5. Tingkat keakuratannya yaitu $83.3333 \%$. Berikutnya yaitu menampilkan pohon keputusan dengan cara klik kanan pada result list, kemudian pilih visualize tree, maka akan muncul Gambar 7.

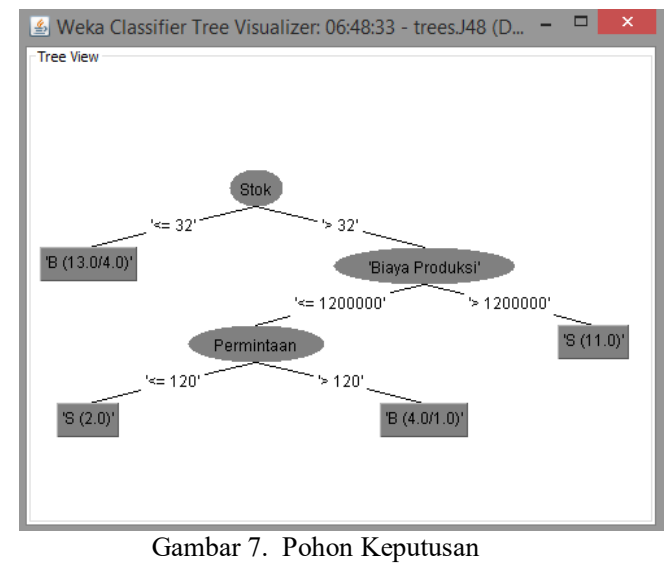

Dari Gambar 7 sehingga dapat disimpulkan bahwa yang terbentuk dari aturan weka batasan datanya adalah sebagai berikut

Stok:

Sedikit: $4<$ Stok $\leq 32$

Banyak: lebih dari 32

Permintaan:

Sedikit: $49<$ Permintaan $\leq 120$

Banyak: lebih dari 120 
Biaya produksi:

Sedikit: Rp $900.000<$ Biaya $\leq$ Rp 1.200.000

Banyak: lebih dari Rp 1.200.000

Sehingga diperoleh rule decision tree yang nampak pada Tabel 2.

\subsection{Data Uji dan Hasil Sistem}

a. Data Uji

Berikut data uji yang akan dibandingkan menggunakan metode fuzzy Tsukamoto dan sugeno menggunakan rule decision tree dari sistem yang peneliti buat:

\begin{tabular}{llllll}
\multicolumn{7}{c}{ Tabel 4. Data Uji } \\
\hline Bulan & Tahun & $\begin{array}{l}\text { Biaya } \\
\text { Produksi }\end{array}$ & $\begin{array}{l}\text { Permi } \\
\text { ntaan }\end{array}$ & Stok & $\begin{array}{l}\text { Jumlah } \\
\text { Produksi }\end{array}$ \\
\hline 03 & 2017 & Rp 6.000.000 & 320 & 60 & 340 \\
04 & 2017 & Rp 5.800.000 & 150 & 100 & 290 \\
05 & 2017 & Rp 8.500 .000 & 420 & 85 & 310 \\
\hline
\end{tabular}

b. Hasil Sistem

Berikut hasil dari sistem yang dihasilkan berdasarkan Tabel.4 Data Uji menggunakan metode fuzzy Tsukamoto dan Sugeno:

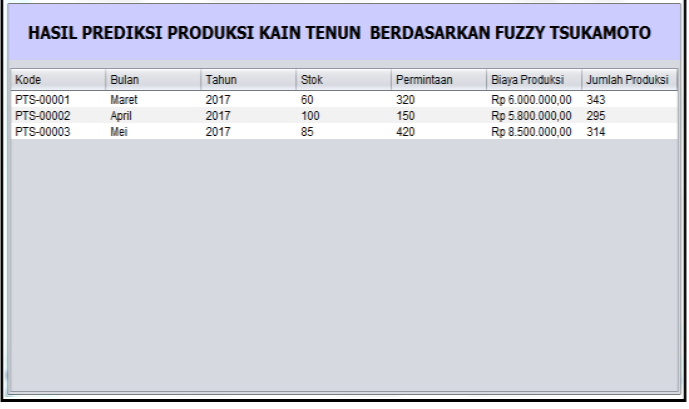

Gambar 8. Hasil Sistem Metode Tsukamoto

Dari Gambar 8 dan Gambar 9, maka dihasilkan nilai antara metode fuzzy Tsukamoto dan Sugeno dengan data sesungguhnya pada bulan Maret, April, dan Mei tahun 2017 adalah sebagai berikut:

Tabel. 5 Hasil Perbandingan

\begin{tabular}{lll}
\multicolumn{3}{c}{ Tabel. } \\
Prediksi Produksi & Prediksi Produksi & Produksi \\
Fuzzy Tsukamoto & Fuzzy Sugeno & Sesungguhnya \\
\hline 343 & 371 & 340 \\
295 & 195 & 290 \\
314 & 478 & 310 \\
\hline
\end{tabular}

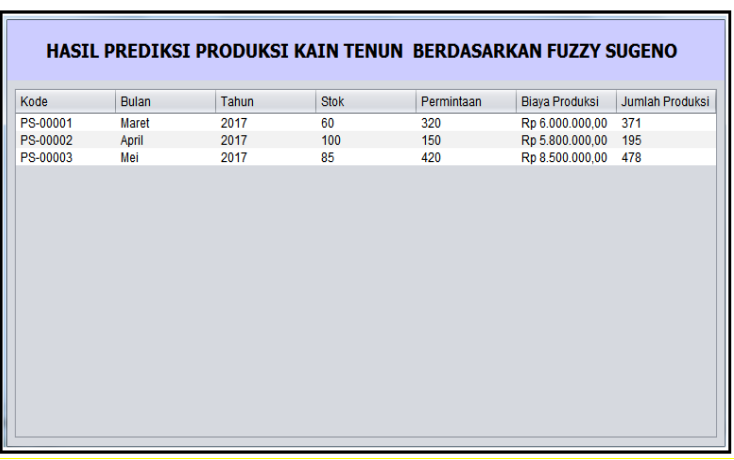

Gambar 9. Hasil Sistem Metode Sugeno
Dari hasil Tabel. 5 Hasil Perbandingan maka dapat ditemukan perbedaan yang sangat signifikan antara metode fuzzy Tsukamoto dan Sugeno adalah sebagai berikut:

a. Metode fuzzy Tsukamoto dari hasil yang diperoleh lebih mendekati dari data sesungguhnya, dibandingkan dengan fuzzy Sugeno.

b.Selisih yang diperoleh dengan menggunakan fuzzy Tsukamoto dengan data produksi sesungguhnya selalu konsisten yaitu hasil fuzzy Tsukamoto selalu lebih besar, sedangkan untuk fuzzy Sugeno tidak konsisten.

c. Hasil selisih untuk fuzzy Tsukamoto relatif mendekati dari data produksi sesungguhnya, sedangkan untuk fuzzy Sugeno relatif jauh selisih yang dihasilkan.

Sehingga dapat diketahui dari tiga sampel di atas bahwa metode yang mendekati dengan hasil produksi sesungguhnya adalah metode Tsukamoto.

\section{PENUTUP}

\subsection{Kesimpulan}

Berdasarkan hasil penelitian mengenai fuzzy Inference System dengan metode Tsukamoto dan Sugeno dapat diambil kesimpulan sebagai berikut:

a. Model basis aturan dalam penelitian ini berupa pohon keputusan yang dapat digunakan untuk Fuzzy Inference System dengan keakuratan $83.3333 \%$.

b. Dari data perhitungan produksi kain tenun Mlaki Wanarejan Utara Pemalang menurut metode Tsukamoto pada bulan Maret, April, dan Mei pada tahun 2017 diperoleh 343, 295, dan 314 kain tenun permeter, sedangkan menggunakan metode Sugeno diperoleh 371, 195, dan 478 kain tenun permeter, sedangkan menurut data produksi perusahaan pada bulan Maret, April, dan Mei tahun 2017 memproduksi 340, 290, dan 310 kain tenun permeter.

c. Dari hasil analisis perbandingan secara langsung dengan data yang sesungguhnya bahwa metode yang paling mendekati nilai kebenaran adalah produksi yang diperoleh dengan mengunakan metode Tsukamoto.

\subsection{SARAN}

Aplikasi ini dapat diimplementasikan pada lembaga industri kain tenun, dengan adanya aplikasi ini diharapkan pengusaha kain tenun dapat lebih mudah dan objektif dalam menentukan jumlah produksi yang sesuai dan tepat berdasarkan data stok, permintaan, serta biaya produksi. Dalam penggunaannya disarankan untuk menyesuaikan parameter yang digunakan. 


\section{DAFTAR PUSTAKA}

HIDAYATI, J. et al. (2013) 'Optimization of Business Partners Feasibility for Oil Palm Revitalization Using Fuzzy Approach', 3(2), pp. 29-35.

JULIANSYAH, A. (2015) 'Penerapan Metode Fuzzy Tsukamoto Untuk Memprediksi Hasil Produksi Kelapa Sawit (Studi Kasus :PT Amal Tani Perkebunan Tanjung Putri-Bahorok)', 4(1), pp. 130-137.

KUSUMADEWI, 2013. Aplikasi Logika Fuzzy Untuk

Pendukung Keputusan, Graha Ilmu Yogyakarta.

SELA, E. I. et al. (2015) 'Feature Selection of the Combination of Porous Trabecular with Anthropometric Features for Osteoporosis Screening', International Journal of Electrical and Computer Engineering (IJECE), 5(1), pp. 78-83.

SELYWITA, D. and HAMDANI (2013) 'Sistem Pendukung Keputusan Pemilihan Supplier Obat Menggunakan Metode Fuzzy Tsukamoto', 3(1), pp. 21-30.

SIGIT, H. / T. A. M. / H. T. (2015) 'Implementation Of Fuzzy-C4.5 Classification As a Decision Support For Students Choice Of Major Specialization', ArXiv.org, 2(11), pp. 15771581.

SOLIKIN, F. (2013) 'Aplikasi Logika Fuzzy Dalam Optimisasi Produksi Barang Menggunakan Metode Mamdani Dan Metode Sugeno', 2013(Sentika).

SUKANDY, D. M., BASUKI, A. T. and PUSPASARI, S. (2014) 'Penerapan Metode Fuzzy Mamdani Untuk Memprediksi Jumlah Produksi Minyak Sawit Berdasarkan Data Persediaan Dan Jumlah Permintaan ( Studi Kasus Pt Perkebunan Mitra Ogan Baturaja )', Program Studi Teknik Informatika, pp. 1-9.

TSENG, T. L. (Bill), KONADA, U. and KWON, Y. (James) (2016) 'A novel approach to predict surface roughness in machining operations using fuzzy set theory', Journal of Computational Design and Engineering. Elsevier, 3(1), pp. 1-13.

TUNDO and SELA, E. I. (2018) 'APPLICATION OF THE FUZZY INFERENCE SYSTEM METHOD TO PREDICT', (IJID) International Journal on Informatics for Development, 7(1), pp. 1-9. 
Halaman ini sengaja dikosongkan 